\title{
Plastic Particles Found in the Gizzard of a Starved Black-footed Albatross (Diomedea nigripes)
}

\author{
Haruo Ogi*, Kunikazu Momose**, Fumio Sato** and Norihisa Baba*** \\ Key words: plastic ingestion, resin pellet, fragments of plastic products, Black-footed \\ Albatross, pica phenomenon
}

A Black-footed Albatross (Diomedea nigripes) was found exhausted on the beach of Hazaki Shinko Port $\left(35^{\circ} 45^{\prime} \mathrm{N}, 140^{\circ} 51^{\prime} \mathrm{E}\right)$, Ibaraki Prefecture, 21 October 1992. This bird was recovered by the staff of the Nature Protection Section, Regional Government of Ibaraki Prefecture. Food and vitamins were force-fed daily, but the bird was so emaciated that it died on 27 October. Its subcutaneous and visceral fat had been completely depleted and its pectoral muscles were considerably reduced. The bird had been banded as a chick on Torishima Island, in the Izu Islands, on 21 April 1992 (Band No. BA-00695), hence it was 9-10 months old. It had spent approximately 4 months at sea after fledging. The cause of death seemed to be starvation.

The digestive tract was sent to the Yamashina Institute for Ornithology. In the gizzard, were 3 squid beaks, 1 plant seed, 47 pebbles, 2 minute pumice stones and 12 plastic particles. No items were in the proventriculus. One of the squid beaks was identified as Chiroteuthis sp. Two plastic particles (Nos. 1 and 2 in Fig. 1 and Table 1) were resin pellets, $3.5 \times 3.8 \times 3.5 \mathrm{~mm}$, or a polyethylene cylinder and pill; the remainder were fragments of plastic products (Nos. 3 to 12) $6.9 \times 9.4 \times 2.0 \mathrm{~mm}$ in size. Particles Nos. 9 and 10 had been burned imperfectly in an incinerator before being shaped under ambient temperature.

Color preference for plastic particles by the Black-footed Albatross has been studied only during the breeding season (Sileo et al. 1990, Sievert and Sileo 1993). In the North Pacific, the color of plastic ingested by Sooty and Short-tailed shearwaters differed (Ogi 1990). The difference may be due to the different food and feeding habits between the two species of shearwaters. However, to properly evaluate color preferences for plastic among seabirds, color must be designated using technical analysis. In this study, we used the CIE $1976 \mathrm{~L}^{*}{ }^{*} \mathrm{~b}^{*}$ method (Anon. 1974, Kuehni 1976), and a Handy Colorimeter (NR-3000, Nippon Denshoku Ind., Ltd.). In Table 1, the $\mathrm{L}^{*}$ denotes the level of brightness ranging from pure black $\left(L^{*}=0\right)$ to pure white $\left(L^{*}=100\right)$. The $a^{*}$ and $b^{*}$ denote the green-red hue axis ranging from pure green to pure red in chroma, and the blue-yellow hue axis

\footnotetext{
Reseived 21 May 1993, Revised 2 December 1993, Accepted 16 December 1993.

* Research Institute of North Pacific Fisheries, Faculty of Fisheries, Hokkaido University, Hakodate, Hokkaido, 041 Japan

** Yamashina Institute for Ornithology, Konoyama, Abiko, Chiba, 270-11 Japan

*** National Research Institute of Far Seas Fisheries, Fisheries Agency of Japan, 7-1 Orido, 5 chome, Shimizu, Shizuoka, 424 Japan
} 


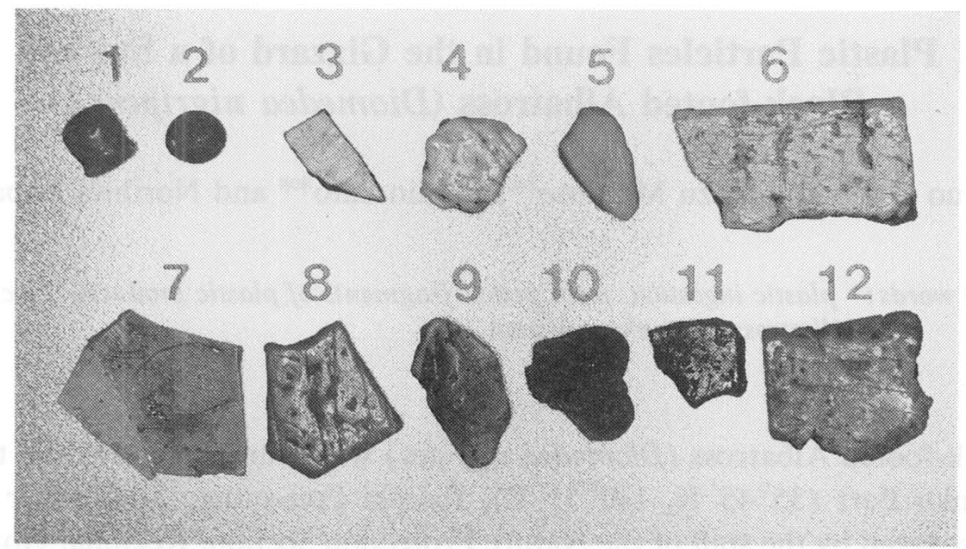

Fig. 1. Plastic particles found in the gizzard of a Black-footed Albatross.

Table 1. Measurements of plastic particles ingested by the Black-footed Albatross. L*: Brightness, a*: Chroma on the Green-Red (G-R) hue axis, b*: Chroma on the Blue-Yellow (B-Y) hue axis.

\begin{tabular}{|c|c|c|c|c|c|c|c|}
\hline \multirow[b]{2}{*}{$\begin{array}{l}\text { Code No. of } \\
\text { plastic particle }\end{array}$} & \multicolumn{4}{|c|}{ Size } & \multicolumn{3}{|c|}{ Color recognition } \\
\hline & $\begin{array}{l}\text { Weight } \\
\text { (mg) }\end{array}$ & $\begin{array}{l}\text { Shortest } \\
\text { length } \\
(\mathrm{mm})\end{array}$ & $\begin{array}{l}\text { Longest } \\
\text { length } \\
(\mathrm{mm})\end{array}$ & $\begin{array}{c}\text { Thickness } \\
(\mathrm{mm})\end{array}$ & $\begin{array}{c}\text { Brightness } \\
\mathrm{L}^{*}\end{array}$ & $\begin{array}{c}\text { Chroma } \\
\text { (G-R hue) } \\
\mathrm{a}^{*}\end{array}$ & $\begin{array}{c}\text { Chroma } \\
\text { (B-Y hue) } \\
\mathrm{b}^{*}\end{array}$ \\
\hline 1 & 36.2 & 3.43 & 3.64 & 4.50 & 45.76 & -6.64 & 14.20 \\
\hline 2 & 20.4 & 3.60 & 4.01 & 2.50 & 46.46 & 4.29 & 13.50 \\
\hline 3 & 23.2 & 3.40 & 7.61 & 1.20 & 96.25 & -1.74 & 7.04 \\
\hline 4 & 58.3 & 5.90 & 6.52 & 2.98 & 86.67 & -1.63 & 16.10 \\
\hline 5 & 50.4 & 4.12 & 8.27 & 2.58 & 67.09 & -0.73 & 9.06 \\
\hline 6 & 233.8 & 7.98 & 15.12 & 2.12 & 85.28 & -2.49 & 11.61 \\
\hline 7 & 84.1 & 10.10 & 10.82 & 0.88 & 51.57 & 4.39 & 9.47 \\
\hline 8 & 73.9 & 9.18 & 9.92 & 1.22 & 52.42 & -0.78 & 7.35 \\
\hline 9 & 74.0 & 5.30 & 10.62 & 3.42 & 60.24 & 0.99 & 8.27 \\
\hline 10 & 65.5 & 6.79 & 7.50 & 3.63 & 28.86 & 1.57 & 3.65 \\
\hline 11 & 18.8 & 5.64 & 6.40 & 0.71 & 32.96 & 1.49 & 5.18 \\
\hline 12 & 101.8 & 10.44 & 11.29 & 1.34 & 57.73 & -4.49 & -16.09 \\
\hline Total & 840.4 & & & & & & \\
\hline Average & 70.0 & 6.32 & 8.48 & 2.26 & 59.27 & -0.48 & 7.45 \\
\hline$\pm \mathrm{SD}$ & 55.5 & 2.47 & 3.13 & 1.16 & 20.27 & 3.13 & 7.93 \\
\hline
\end{tabular}

ranging from pure blue to pure yellow in chroma, respectively. The ranges of the chroma from -10 to +10 in $\mathrm{a}^{*}$ and $\mathrm{b}^{*}$ are difficult to classify by human eyes. The plastic particles in this study were mostly worn to dull color, except for No. 12, which was blue. However, as shown in Table 1, the value of brightness varied from 28.9 to 96.3 , more than those of $a^{*}$ and $b^{*}$. Therefore the plastic particles could be classified as follows: white (particle Nos. 3, 4, 5, and 6), grey (particle Nos. 1, 2, 7, 8, 9), and dark grey (particle Nos. 10 and 11). 
In pelagic waters of the North Pacific Ocean, the average number and weight of plastic particles ingested by Black-footed Albatrosses were as follows: $1.3 \pm 0.7$ particles,

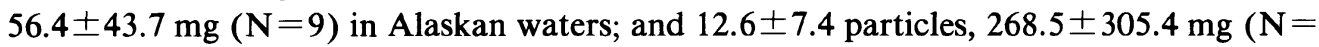
5 ) in Hawaiian waters (Ogi unpubl. data). Thus, the hatching-year albatross in this study had taken more plastic than on average. During the chick stage at breeding colonies on Midway Island, plastic particles are fed often to the chicks by parents; weights average 43 $\mathrm{g}(\mathrm{n}=25$, range $0-219 \mathrm{~g})$ in 1986 and $36 \mathrm{~g}(\mathrm{n}=18$, range 6-182 $\mathrm{g}$ ) in 1987 (Sileo et al. 1990). Sileo et al. (1990) also reported that Black-footed Albatross chicks regurgitate the plastic in their proventriculus before fledging. Until this time, the plastic would remain in the gizzard. The average residence time of plastic particles ingested by Short-tailed Shearwaters (Puffinus tenuirostris) was 10 months with a range of 3 to 12 months (Day 1980). If these rates are applied to the Black-footed Albatross in this study, most of the plastic particles found in the gizzard may have been fed by its parent during chick stage. The death of this bird seemed not to be caused by the ingested plastic because of its small amount.

We thank Dr. Tsunemi Kubodera of the Department of Zoology, National Science Museum, Shinjuku-ku, Tokyo, for identification of squid beaks, and Dr. Noriaki Miura of the Department of Applied Physics, Faculty of Engineering, Hokkaido University, for his advice on the color designation method. We would like to express our sincere thanks to Dr. D. G. Ainley, Point Reyes Bird Observatory, California, for his kind editing for the earlier draft of this manuscript.

\section{References}

Anon. 1974. Proposal for study of color spaces and color-difference evaluation. (Technical Note) J. Opt. Soc. Am. 64: 896-897.

Day, R. H. 1980. The occurrence and characteristics of plastic pollution in Alaska's marine birds. M. S. Thesis, Univ. Alaska, Fairbanks, 111 p.

Kuehni, R. G. 1976. Color-tolerance data and the tentative CIE 1976 L*a*b* formula. J. Opt. Soc. Am. 66: 497-500.

Ogi, H. 1990. Ingestion of plastic particles by Sooty and Short-tailed Shearwaters in the North Pacific. In Proceedings of the Second International Conference on Marine Debris, 2-7 April 1989, Honolulu, HI. (Eds. by R. S. Shomura \& M. L. Godfrey) pp. 635-652, U. S. Dep. Commer., NOAA Tech. Memo. NMFS, NOAA-TM-NMFS-SWFSC-154.

Sievert, P. R. \& Sileo, L. 1993. The effects of ingested plastic on growth and survival of albatross chicks. In The status, ecology, and conservation of marine birds of the North Pacific. (Eds. by K. Vermeer, K. T. Briggs, K. H. Morgan, \& D. Siegel-Causey) pp. 665-681, Can. Wildl. Serv. Spec. Publ., Ottawa.

Sileo, L., Sievert, P. R., Samuel, M. D. \& Fefer, S. I. 1990. Prevalence and characteristics of plastic ingested by Hawaiian seabirds. In Proceedings of the Second International Conference on Marine Debris, 2-7 April 1989, Honolulu, HI. (Eds. by R. S. Shomura \& M. L. Godfrey) pp. 665-681, U. S. Dep. Commer., NOAA Tech. Memo. NMFS, NOAA-TM-NMFS-SWFSC-154. 


\section{茨城県波崎新港で衰弱死したクロアシアホウドリの胃中から \\ 見出されたプラスチック粒子}

1 羽のクロアシアホゥドリが 1992 年 10 月 21 日に茨城県波崎新港で衰弱し保護され，同年 10 月 27 日に 落鳥した。標識番号から，このクロアシアホゥドリは 1992 年 4 月 21 日に鳥島で㮲時に標識付後放鳥され た個体であり，艀化後約 5 ケ月目で巣立ち，海洋生活期の 4 ケ月目で飢餓のため死亡した個体と考えられ た。

胃内容物を調べた結果, 砂囊から 12 個のプラスチック粒子が出現した。粒子の種類はプラスチック原材 料粒子（レジンペレット）が 2 個，他は全てプラスチック製品類の破片であった。平均重量は 70 $\pm 56 \mathrm{mg}$, 色は白色 4 個, 灰色 5 個, 濃灰色 2 個, そして淡青色 1 個であった。

クロアシアホゥドリは巣立ち時に前胃中のプラスチック粒子などの異物を全て吐き出してしまうものの (Sileo et al. 1993), 砂糞中のプラスチック粒子はそのまま保持されている可能性が高い。ハシボソミズナギ ドリでのプラスチック粒子類の胃滞在時間は約 10 力月（範囲：3-12 力月）である (Day 1980)。これらのこ とから，クロアシアホゥドリの胃中に見出されたプラスチック粒子類の多くは，繁殖地において親鳥から 与えられた餉の中に混入し，宩立ち後も砂輷中に残存していた可能性が高い。

小城春雄：北海道大学水産学部, 北洋水産研究施設, $\mathbf{T} 041$ 北海道函館市港町 3-1-1

百瀬邦和, 佐藤文男：財団法人 山階鳥類研究所, テ270-11 千葉県我孫子市高野山字堤根 115

馬場徳寿：水産庁，遠洋水産研究所， $\mathbf{T} 424$ 静岡県清水市折戸 5-7-1 